\title{
PENGARUH RASIO CAMPURAN BERAS KETAN DAN KACANG LEBUI TERHADAP KADAR ANTOSIANIN DAN SIFAT SENSORIS KERIPIK JAJE TUJAK, JAJANAN TRADISIONAL KHAS LOMBOK
}

\section{[The Effect of Sticky Rice and Pigeon Pea Mix Ratio on Total Anthocyanin and Sensory Properties Jaje Tujak Chips, a Lombok Traditional Snack Food]}

Widiyastuti*, Nazaruddin, dan Dody Handito

Fakultas Teknologi Pangan dan Agroindustri, Universitas Mataram

*Email: widias997@gmail.com

Diterima 07 Mei 2019/ Disetujui 06 November 2019

\begin{abstract}
Jaje tujak was a Lombok's traditional snack food that has a short shelf life and lacks other nutrients besides carbohydrates. The aim of this research was determined the optimal ratio of sticky rice and pigeon pea on nutritional components and sensory of jaje tujak chips. This research used a Completely Randomized Design (CRD) with single factor was the proportion of sticky rice and pigeon pea with three replications. Data were analyzed by analysis of variance (ANOVA) at 5\% level using software Co-Stat, if there was difference, then tested further with Orthogonal Polynomial Method (OPM). The result showed that the ratio of sticky rice and pigeon pea had significant on anthocyanin levels, antioxidant activity, moisture, ash and sensory properties including hedonic (texture, color and taste) and scoring properties (texture, color, taste and aroma) but non significant on aroma (hedonic method). The results showed that the highest anthocyanin levels was $\angle 5$ were $47.67 \mathrm{ppm}$ and $63 \%$ antioxidant activity with $1.77 \%$ moisture and $5.31 \%$ ash. The result showed that The best treatment showed by $L 3$ (70\%:30\%) seen from the sensory texture, color, taste and aroma which was favored by the panelists and in scoring which had a assessment of texture was slightly crunchy, slightly white color, slightly pigeon pea's taste and not slightly pigeon pea's aroma; with 34.23 ppm anthocyanin levels, 50.33\% antioxidant activity, $2.01 \%$ moisture and $3.57 \%$ ash.
\end{abstract}

Keywords: Chips, jaje tujak, pigeon pea.

\section{ABSTRAK}

Jaje tujak merupakan jajanan tradisional khas Lombok yang mempunyai umur simpan pendek dan kurang zat gizi lain selain karbohidrat. Tujuan dari penelitian ini adalah untuk menentukan rasio campuran yang terbaik antara beras ketan dan kacang lebui terhadap komponen gizi dan sensoris keripik jaje tujak. Rancangan percobaan yang digunakan adalah Rancangan Acak Lengkap (RAL) dengan faktor tunggal yaitu proporsi beras ketan dan kacang lebui dengan tiga kali ulangan. Data hasil pengamatan dianalisis dengan analisis keragaman pada taraf $5 \%$ menggunakan aplikasi Co-Stat, apabila terdapat perbedaan yang nyata, maka diuji lanjut dengan menggunakan Metode Ortogonal Polinomial (MOP). Hasil penelitian menunjukkan bahwa proporsi beras ketan dan kacang lebui berpengaruh nyata terhadap kadar antosianin, aktivitas antiosidan, kadar air, kadar abu, hedonik (tekstur, warna, rasa) dan scoring (testur, warna, rasa dan aroma), namun tidak berpengaruh nyata terhadap aroma secara hedonik. Hasil penelitian menunjukkan bahwa kadar antosianin tertinggi yaitu L5 sebesar 47,67 ppm dan aktivitas antioksidan 63\% dengan kadar air 1,77\% dan kadar abu 5,31\%. Proporsi beras ketan dan kacang lebui pada L3 (70\%:30\%) merupakan hasil terbaik dilihat dari sensoris tekstur, warna, rasa dan aroma yang agak disukai oleh panelis dan secara scoring tekstur agak renyah, berwarna agak putih, agak berasa lebui dan agak tidak beraroma lebui, dengan total antosianin 34,23 ppm, aktivitas antioksidan 50,33\%, kadar air $2,01 \%$ dan kadar abu 3,57\%.

Kata kunci: Jaje tujak, lebui, keripik.

\section{PENDAHULUAN}

Makanan tradisional merupakan makanan yang dikonsumsi oleh golongan etnik dan wilayah spesifk di suatu daerah (Wardhanu, 2009). Setiap daerah mempunyai makanan tradisonal masing-masing yang mempunyai keunggulan atau kistimewaan 
sendiri. Salah satu daerah di Indonesia yang mempunyai makanan tradisional yaitu Lombok dengan jajanan tradisional jaje tujak.

Jaje tujak dalam bahasa Indonesia berarti jajan tumbuk yaitu jajan yang dibuat dengan cara ditumbuk, di daerah Jawa disebut dengan jadah atau tetel. Sukenti, dkk., (2016) menyatakan bahwa jaje (penganan) banyak disajikan pada waktu upacara agama atau acara perayaan, selain itu juga dikonsumsi dan disajikan oleh rumah tangga suku sasak untuk menyambut para tamu yang datang berkunjung. Pada hari-hari biasa jaje tujak jarang ditemukan dan sebagian besar masyarakat tidak tertarik membuatnya karena cara pembuatan yang sedikit rumit serta menghabiskan banyak tenaga karena melalui proses penumbukan.

Air atau kadar air pada jaje tujak relatif tinggi yang menyebabkan umur simpan menjadi pendek yaitu maksmal 5 hari namun dengan kondisi sudah tidak layak konsumsi, kerusakan jaje tujak sudah dapat diketahui dalam penyimpanan selama 3 hari dengan ditandai oleh rasa yang sudah berubah (tidak normal) serta tekstur yang sudah mengeras. Kerusakan ini diantaranya disebabkan adanya pertumbuhan mikroorganisme terutama jenis kapang yang menyukai lingkungan lembab dan ketersediaan nutrisi yang cukup berupa karbohidrat atau gula kompleks yang terkandung dalam jaje tujak. Kerusakan pada jaje tujak dapat dihambat dengan cara mengurangi kadar air, salah satu cara yaitu dengan metode pengeringan dan mengubah bentuk menjadi keripik.

Keripik merupakan makanan camilan (snack) yang mempunyai daya awet yang cukup tinggi, rasa yang enak dan variasi yang banyak sehingga dapat memenuhi selera konsumen. Keripik merupakan produk olahan pangan yang menggunakan bahan baku secara langsung tanpa ada pencampuran dengan bahan lain seperti tapioka, terigu atau pati yang lain sebagai bahan pengisi. Keripik biasanya diproses dari bahan baku dalam bentuk irisan (hasil perajangan bahan baku) melalui proses penjemuran atau tanpa penjemuran, kemudian digoreng (Estiasih, 2010).

Kendala lain yaitu jaje tujak termasuk makanan yang kaya akan karbohidrat dan kurang nutrisi protein, lemak, vitamin, mineral maupun senyawa bioaktif seperti antioksidan. Menurut Sigiyono (2002), beras ketan (Oryza sativa glatinus) termasuk serealia yang kaya akan karbohidrat sehingga dapat digunakan sebagai makanan pokok manusia dengan komponen kimia yang paling utama pada serealia adalah karbohidrat, terutama pati, kira-kira $80 \%$ dari bahan kering. Untuk memperbanyak nutrisi perlu penambahan zat gizi protein dan antosianin pada jaje tujak guna meningkatkan nilai gizi. Salah satu sumber antosianin dan protein yang jarang dimanfaatkan, murah dan mudah didapatkan khususnya di daerah Lombok, yaitu kacang lebui.

Polong kacang lebui dapat dijadikan sebagai obat memar (Pusat Kajian Holtikuktura Tropika IPB, 2016). Ananto (2017), menunjukkan bahwa lebui mempunyai kadar air 11,36\%, kadar abu 4,11\% dan kadar antosianin sebesar $46,76 \mathrm{mg} / 100 \mathrm{~g}$ bahan. Lebui atau kacang gude merupakan jenis tanaman lokal yang potensial sebagai pangan alternatif di pulau Lombok berdasarkan bobot pemanfaatan dan bobot pengetahuan sebesar 0,07 dengan sebaran seragam yaitu sebagian besar lebui tersebar merata atau seragam di seluruh wilayah di pulau Lombok.

Penambahan kacang-kacangan pada produk dapat dilakukan dengan cara mengatur proporsi atau perbandingan dengan bahan lain secara tepat. Jayadi, dkk., (2012) dalam penelitiannya menunjukkan bahwa penggunaan persentase tepung kedelai $10 \%$ untuk membuat Sakko-sakko atau makanan ringan tradisional khas suku Bugis dan Makassar memberikan hasil terbaik. Marom (2013) juga menunjukkan bahwa substitusi tepung terigu dengan kulit ari biji kedelai yaitu 90\%:10\% merupakan perlakuan yang terbaik. Thomas, dkk., (2017) menunjukkan bahwa dengan penambahan tepung kedelai $25 \%$ menghasilkan biskuit yang paling disukai oleh panelis. Tujuan penelitian ini adalah untuk 
Versi Online:

http://www.profood.unram.ac.id/index.php/profood e-ISSN: 2443-3446

mengetahui pengaruh rasio campuran beras ketan dan bubuk lebui terhadap kadar antosianin dan sifat sensoris keripik jaje tujak khas Lombok.

\section{BAHAN DAN METODE}

\section{Bahan dan Alat}

Bahan-bahan yang digunakan adalah beras ketan putih varietas bontok yang dibeli dari pasar Narmada Lombok Barat, lebui yang dibeli dari pasar Sweta Lombok Barat, garam, kelapa, air, minyak goreng, aquades, methanol, $\mathrm{HCl}$, Buffer $\mathrm{KCl} \mathrm{pH} 1$ dan Buffer Asetat $\mathrm{pH} 4,5$.

Alat-alat yang digunakan adalah timbangan analitik, botol timbang, oven, desikator, tanur pengabuan, penjepit cawan, spektrofotometer UV-Vis, cawan pengabuan, neraca analitik, gelas kimia, labu ukur, tabung reaksi, Erlenmeyer, corong pisah, kertas saring, shaker, refrigerator, kompor, alu, nampan, pisau, panci, blender, baskom, thermometer dan ember.

\section{Metode}

Rancangan penelitian yang digunakan adalah Rancangan Acak Lengkap (RAL) dengan faktor tunggal yaitu rasio campuran beras ketan dan kacang lebui (L). Penelitian yaitu dengan perlakuan proporsi beras ketan: bubuk lebui sebagai berikut:

$\mathrm{L}_{0}=100 \%$ beras ketan: $0 \%$ bubuk lebui

$\mathrm{L}_{1}=90 \%$ beras ketan: $10 \%$ bubuk lebui

$\mathrm{L}_{2}=80 \%$ beras ketan: $20 \%$ bubuk lebui

$\mathrm{L}_{3}=70 \%$ beras ketan: $30 \%$ bubuk lebui

$\mathrm{L}_{4}=60 \%$ beras ketan: $40 \%$ bubuk lebui

$\mathrm{L}_{5}=50 \%$ beras ketan: $50 \%$ bubuk lebui

Masing-masing perlakuan diulang sebanyak 3 kali sehingga diperoleh 18 unit percobaan. Analisis data hasil pengamatan menggunakan ANOVA (Analysis of Variance) dengan taraf signifikansi $5 \%$ menggunakan software Co-Stat. Adanya perbedaan nyata antar perlakuan diuji lanjut menggunakan uji lanjut Metode Ortogonal Polinomial (MOP) dan Beda Nyata Jujur (BNJ) untuk parameter sensoris.

\section{Pelaksanaan Penelitian}

\section{Perlakuan Pendahuluan Kacang Lebui}

kacang lebui yang ditambahkan pada pembuatan jaje tujak, terlebih dahulu dibuat menjadi bubuk lebui dengan cara yaitu pertama pemilihan bahan baku yang berkualitas baik, pencucian, pengukusan selama 8 menit pada suhu $70^{\circ} \mathrm{C}$, perendaman dalam air selama 1 menit dengan perbandingan air dan kacang lebui yaitu 3:2, penirisan untuk menghilangkan air yang menempel pada kacang lebui, penggilingan dengan blender dan terakhir pengayakan menggunakan ayakan 60 mesh.

\section{Pembuatan Keripik Jaje Tujak}

Bahan utama yang digunakan pada pembuatan jaje tujak yaitu beras ketan dan bahan tambahan yaitu garam, bubuk lebui dan kelapa yang sudah diparut. Proses dimulai dari pemilihan bahan baku yang berkualitas tinggi kemudian dilakukan pencucian, setelah itu direndam selama 1,5 jam dan ditiriskan selama 1-2 jam untuk mengurangi air pada beras ketan. Kemudian dikukus yaitu pengukusan I pada suhu $70^{\circ} \mathrm{C}$ selama 30 menit hingga didapatkan beras ketan yang setengah matang, pencampuran bahan yaitu menggunakan garam $5 \mathrm{~g}$ dan parutan kelapa $50 \mathrm{~g}$ kemudian diaduk hingga merata. Selanjutnya dilakukan pengukusan II pada suhu $70^{\circ} \mathrm{C}$ selama 20 menit dengan ditandai semua bahan sudah matang. Kemudian ditumbuk dan ditambahkan bubuk lebui dengan konsentrasi $0 \%, 10 \%, 20 \%, 30 \%$, $40 \%$ dan $50 \%$ dalam kondisi masih panas agar mudah dibentuk, selanjutnya yaitu pendinginan di dalam refrigerator selama 12 jam yang bertujuan untuk mengeraskan tekstur jaje tujak sehingga mudah untuk diiris. Tahap selanjutnya yaitu pengirisan jaje tujak menggunakan cuter dengan ketebalan $1 \mathrm{~mm}$, hasil pengirisan jaje tujak kemudian di jemur dibawah sinar matahari selama 2 hari (16 jam). Terakhir yaitu proses penggorengan dengan metode deep fat fryed dengan volume minyak $500 \mathrm{~mL}$ pada suhu $150^{\circ} \mathrm{C}$ selama 20 detik. 


\section{HASIL DAN PEMBAHASAN}

\section{Total Antosianin}

Antosianin merupakan pigmen yang banyak terdapat pada bahan yang berwarna merah. Antosianin termasuk golongan senyawa flavonoid yang memberi warna merah, merah keunguan, ungu muda dan ungu tua pada buah dan sayuran. Kandungan antosianin pada bahan berbeda-beda. Selain ditentukan oleh varietasnya, kandungan antosianin tersebut juga bergantung pada kematangan bahan pangan, semakin tua dan semakin merah maka kandugan antosianin semakin tinggi. Meskipun tidak memberi asupan nutrisi secara khusus, antosianin memiliki peran penting untuk menjaga kesehatan karena antosianin berguna sebagai zat antikanker dan antioksidan (Lingga, 2012). Berdasarkan analisis keragaman (ANOVA), menunjukkan bahwa perlakuan proporsi beras ketan dan bubuk lebui berpengaruh nyata terhadap total antosianin keripik jaje tujak.

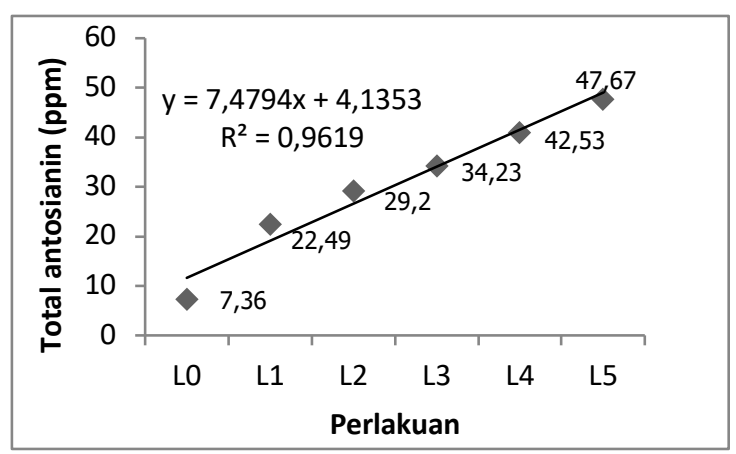

Gambar 1. Grafik Pengaruh Proporsi Beras Ketan dan Bubuk Lebui Terhadap Total Antosianin Keripik Jaje Tujak

Berdasarkan Gambar 1, menunjukkan bahwa semakin tinggi penambahan kacang lebui maka total antosianin keripik jaje tujak semakin meningkat dengan pola regresi yang terbentuk yaitu linier dengan persamaan $y=7,4794 x+4,1353$ dengan koefisien deteminasi $R^{2}=0,9619$ atau $96,19 \%$. Nilai 96,19\% menunjukkan bahwa total antosianin dipengaruhi sebesar $96,19 \%$ oleh proporsi beras ketan dan bubuk lebui. Semakin banyak penambahan bubuk lebui maka total antosianin semakin meningkat. $\mathrm{Hal}$ ini dikarenakan bubuk lebui mengandung senyawa antosianin yang dapat diketahui dari warna kulitnya. Antosianin pada produk kacang lebui dengan kulit lebih tinggi dari pada lebui yang diolah tanpa kulit. Nurrahman (2015), kelebihan dari kedelai hitam mengandung antosianin. Ananto (2017) dalam penelitiannya menunjukkan bahwa kadar antosianin sayur lebui sebesar $46,76 \mathrm{mg} / 100 \mathrm{~g}$ bahan.

\section{Aktivitas Antioksidan}

\begin{tabular}{llrr}
\multicolumn{2}{c}{ Antioksidan diartikan } & sebagai \\
sekumpulan & senyawa & yang & mampu \\
menghambat & berbagai & reaksi & oksidasi,
\end{tabular} sehingga sangat efektif untuk memperpanjang umur simpan bahan pangan atau memelihara kesehatan sebagai akibat proses oksidasi berlebih (Firdaus, dkk., 2013). Berdasarkan analisis keragaman (ANOVA), menunjukkan bahwa perlakuan proporsi beras ketan dan bubuk lebui berpengaruh nyata terhadap aktivitas antioksidan keripik jaje tujak.

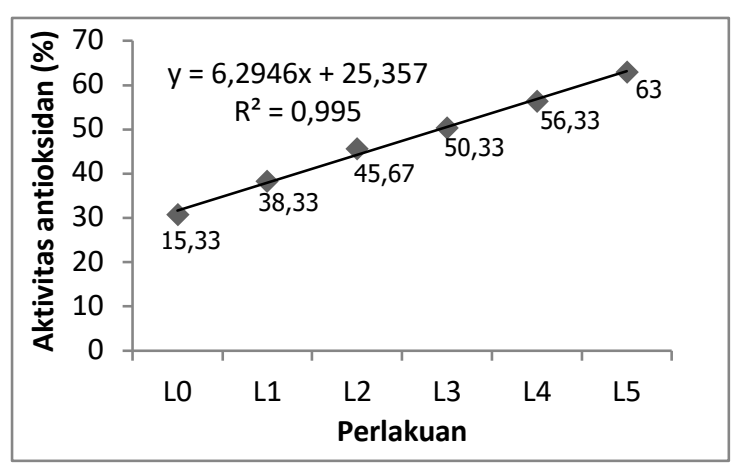

Gambar 2. Grafik Pengaruh Proporsi Beras Ketan dan Bubuk Lebui Terhadap Aktivitas Antioksidan Keripik Jaje Tujak

Berdasarkan Gambar 2, menunjukkan bahwa semakin tinggi penambahan kacang lebui maka aktivitas antioksidan semakin tinggi dengan pola regresi yang terbentuk yaitu linier dengan persamaan $y=6,294 x+25,35$ dan dengan koefisien determinasi (KD) $R^{2}=0,995$ atau $99,5 \%$. Nilai $99,5 \%$ menunjukkan bahwa aktivitas antioksidan dipengaruhi sebesar $99,5 \%$ oleh proporsi beras ketan dan bubuk lebui. Semakin banyak penambahan bubuk lebui maka aktivitas antioksidan semakin 
meningkat. Hal ini dikarenakan lebui memiliki antosianin, antosianin merupakan salah satu jenis antioksidan yang berperan penting bagi kesehatan. Kandungan antosianin menunjukkan hubungan yang positif dengan aktivitas antioksidan. Semakin tinggi kandungan antosianin maka aktivitas antioksidan semakin besar (Sarepoua, dkk., 2013).

\section{Kadar Air}

Bahan pangan terdiri dari bahan kering ditambah sejumlah air. Air dalam bahan pangan merupakan bagian seutuhnya dari bahan pangan itu sendiri (Effendi, 2012). Air yang terkandung dalam bahan pangan khususnya air bebas merupakan salah satu faktor penyebab kerusakan bahan pangan, air dibutuhkan oleh mikroba untuk pertumbuhannya. Demikian juga air dibutuhkan untuk berlangsungnya reaksireaksi biokimia yang terjadi di dalam bahan pangan, misalnya reaksi-reaksi yang dikatalisis oleh enzim (Sudiarto dan Gusmaini, 2004). Kandungan air pada bahan makanan sangat menentukan acceptability, kesegaran dan masa simpan bahan tersebut (Winarno, 2004). Berdasarkan analisis keragaman (ANOVA), menunjukkan bahwa perlakuan proporsi beras ketan dan bubuk lebui berpengaruh nyata terhadap kadar air keripik jaje tujak.

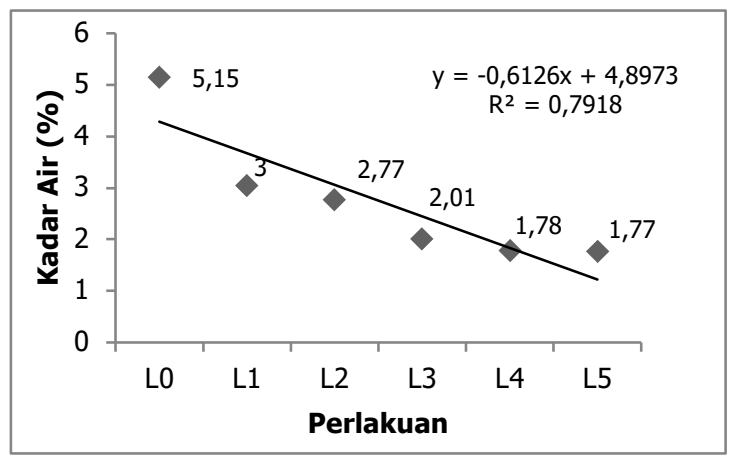

Gambar 3. Grafik Pengaruh Proporsi Beras Ketan dan Bubuk Lebui Terhadap Kadar Air Keripik Jaje Tujak

Berdasarkan Gambar 3, menunjukkan bahwa semakin tinggi penambahan kacang lebui maka kadar air semakin menurun dengan pola regresi yang terbentuk yaitu linier dengan persamaan $\mathrm{y}=-0,612 \mathrm{x}+4,897$ dan dengan koefisien determinasi (KD) $R^{2}=0,791$ atau $79,1 \%$. Nilai $79,1 \%$ menunjukkan bahwa penurunan kadar air dipengaruhi sebesar $79,1 \%$ oleh proporsi beras ketan dan bubuk lebui. Semakin tinggi penambahan bubuk lebui maka kadar air semakin menurun. Hal ini disebabkan karena kadar air bahan baku yang digunakan berbeda, kadar air beras ketan yaitu sebesar 16,24\% (Suriani, 2015) dan kacang lebui sebesar 11,36\% (Ananto, 2017). Hasil ini sejalan dengan penelitian Nurali, dkk. (2010), yang menyatakan bahwa semakin besar penambahan proporsi tepung kedelai maka akan mengahsilkan tekstur yang keras pada flakes ubi jalar. Menurut Ramdani (2018) dalam penelitiannya bahwa, semakin meningkatnya penambahan konsentrasi tepung porang maka daya ikat pada pembuatan fruit lather akan meningkat, karena tepung porang yang ditambahkan dalam pembuatan fruit lather merupakan bahan yang paling banyak menyerap air selama proses pengolahan.

\section{Kadar Abu}

Kadar abu menentukan besarnya bahan anorganik (total mineral) di dalam suatu bahan pangan maupun produk makanan. Hubungan kadar abu dengan total mineral yaitu semakin besar kadar abu maka semakin banyak kandungan mineral di dalam produk tersebut, seperti kadungan kalsium, besi, fosfor, kalium dan lain-lain. Bahan anorganik dalam suatu bahan sangat bervariasi dan dengan jumlah yang berbedabeda (Wibowo, 2012). Berdasarkan analisis keragaman (ANOVA), menunjukkan bahwa perlakuan proporsi beras ketan dan bubuk lebui berpengaruh nyata terhadap kadar abu keripik jaje tujak.

Berdasarkan Gambar 4, menunjukkan bahwa semakin tinggi penambahan kacang lebui maka kadar abu semakin tinggi dengan pola regresi yang terbentuk yaitu linier dengan persamaan $y=0,6654 x+1,136$ dan koefisien determinasi $R^{2}=0,9606$ atau $96,06 \%$. Nilai $96,06 \%$ menunjukkan bahwa peningkatan kadar abu dipengaruhi sebesar $96,06 \%$ oleh 
proporsi beras ketan dan bubuk lebui. Kadar abu keripik jaje tujak semakin meningkat seiring dengan pengurangan proporsi beras ketan dan penambahan proporsi bubuk lebui. Hal ini dikarenakan perbedaan kadar abu dari bahan baku yang digunakan. Kadar abu beras ketan yaitu sebesar $0,24 \%$ dan kadar abu kacang lebui sebesar 5,57\% (Oshodi dan Ekperigin, 1989).

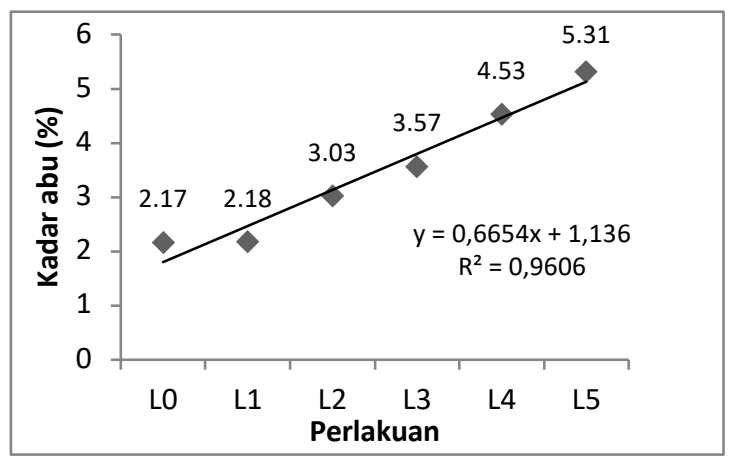

Gambar 4. Grafik Pengaruh Proporsi Beras Ketan dan Bubuk Lebui Terhadap Kadar Abu Keripik Jaje Tujak

Kandungan mineral kacang lebui yaitu kalsium $12,5 \mathrm{mg}$, fosfor $275 \mathrm{mg}$ dan besi 4 mg (Depkes RI, 1981). Tumbel dan Manurung (2017), dalam penelitiannya menyatakan bahwa kadar abu dipengaruhi oleh suhu, semakin tinggi suhu yang digunakan maka semakin besar air yang hilang karena teruapkan sehingga mengakibatkan semakin besar kadar abu yang dihasilkan. Hasil penelitian ini didukung oleh hasil penelitian Salviana (2018) dan Nurali (2010) sama-sama menunjukkan bahwa kadar abu flakes semakin meningkat yaitu $1,47-3,21 \%$ seiring dengan penambahan tepung kacang lebui dan meningkat dari 3,75-5,20\% pada penambahan tepung kacang kedelai.

\section{Sensoris Tekstur}

Tekstur atau kerenyahan merupakan salah satu faktor terpenting atau karakter utama dari keripik/snack. Tekstur suatu produk sangat dipengaruhi oleh kandungan air yang ada pada suatu produk, semakin tinggi kadar air maka tingkat kerenyahan semakin kecil begitupun sebaliknya, semakin rendah kadar air atau kandungan air pada produk maka tekstur yang dihasilkan akan semakin tinggi (renyah) (Astawan, 2004). Berdasarkan analisis keragaman (ANOVA), menunjukkan bahwa perlakuan proporsi beras ketan dan bubuk lebui berpengaruh nyata terhadap tekstur secara hedonik dan scoring keripik jaje tujak.

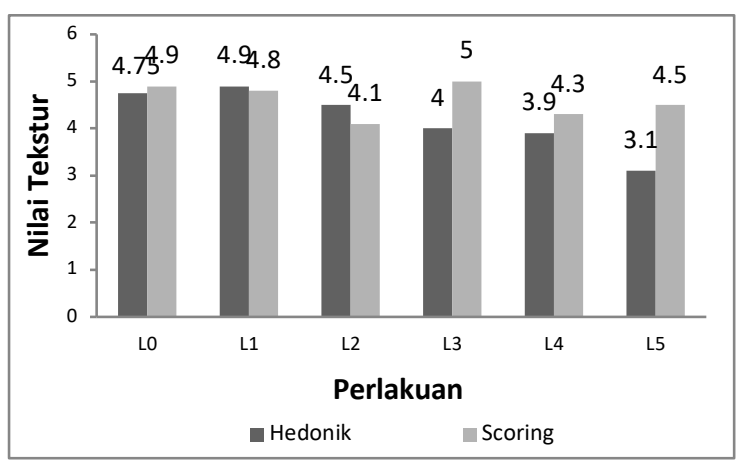

Gambar 5. Grafik Pengaruh Proporsi Beras Ketan dan Bubuk Lebui Terhadap Mutu Sensoris Tekstur Keripik Jaje Tujak

Berdasarkan Gambar 5, menunjukkan bahwa rata-rata panelis memberikan nilai tekstur keripik jaje tujak terhadap tingkat kesukaan (hedonik) berkisar antara 3,1-4,9 (agak tidak suka sampai agak suka). Berdasarkan tingkat penilaian (scoring) ratarata panelis memberikan nilai pada rentang 4,1-5 (agak renyah sampai renyah).

Semakin tinggi penambahan bubuk lebui maka tekstur keripik jaje tujak semakin keras atau rapuh dan mudah hancur. Hal ini karena bubuk lebui mempunyai kadar air yang lebih rendah dari beras ketan sehingga tekstur keripik mudah rapuh. Menurut Jauhariah (2013), semakin tinggi kadar air maka tekstur keripik akan menjadi lebih sulit untuk dipatahkan. Menurut Putra (2018), kerenyahan keripik dipengaruhi oleh kandungan protein yang terkandung di dalam bahan. Hal ini dikarenakan kemampuan protein dalam mengikat air yang membuat terganggunya proses pengembangan granula pati. Berdasarkan uraian tersebut maka dapat diketahui bahwa perlakuan terbaik untuk tekstur dengan kriteria agak renyah yaitu perlakuan L3 (70\%:30\%). 


\section{Sensoris Warna}

Warna atau kenampakan merupakan atribut mutu yang pertama kali ditangkap oleh konsumen daripada atribut mutu lainnya. Oleh karena itu warna sangat menentukan daya terima terhadap produk (Kartika, 1990). Berdasarkan analisis keragaman (ANOVA), menunjukkan bahwa perlakuan proporsi beras ketan dan bubuk lebui berpengaruh nyata terhadap warna secara hedonik dan scoring keripik jaje tujak.

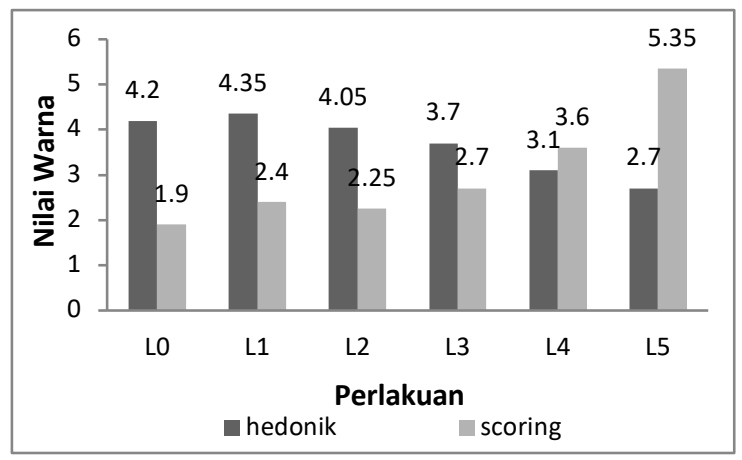

Gambar 6. Grafik Pengaruh Proporsi Beras Ketan dan Bubuk Lebui Terhadap Mutu Sensoris Warna Keripik Jaje Tujak

Berdasarkan Gambar 6, menunjukkan bahwa rata-rata panelis memberikan nilai warna keripik jaje tujak terhadap tingkat kesukaan (hedonik) berkisar antara 2,7-4,35 (tidak suka sampai agak suka). berdasarkan tingkat penilaian (scoring) rata-rata panelis memberikan nilai pada rentang 1,9-5,35 (putih sampai coklat).

Secara scoring semakin banyak kacang lebui yang ditambahkan maka semakin tinggi tingkat penilaian warna yaitu berwarna coklat (perlakuan L5). Hal ini dikarenakan warna lebui yang ungu tua sampai hitam akan menyebabkan keripik jaje tujak yang dihasilkan berwarna coklat. Selain itu, warna coklat juga disebabkan oleh adanya reaksi browning nonenzimatis pada saat proses pengolahan. Putra (2018), warna coklat pada keripik jagung dapat disebabkan karena adanya reaksi browning nonenzimatis, dimana karbohidrat akan bereaksi dengan protein bila ada panas pada saat proses pengolahan. Berdasarkan uraian tersebut maka dapat diketahui bahwa perlakuan terbaik untuk warna dengan kriteria berwarna agak putih yaitu perlakuan L3 (70\%:30\%).

\section{Sensoris Rasa}

Rasa adalah persepsi dari indera pengecap yang meliputi rasa asin, manis, asam dan pahit yang diakibatkan oleh bahan yang terlarut dalam mulut (Meilgaard et al dalam Thomas, dkk., 2017). Rasa merupakan atribut mutu terpenting setelah warna dan aroma, rasa menentukan penerimaan atau penolakan konsumen terhadap suatu produk. Berdasarkan analisis keragaman (ANOVA), menunukkan bahwa perlakuan proporsi beras ketan dan bubuk lebui berpengaruh nyata terhadap rasa secara hedonik dan scoring keripik jaje tujak.

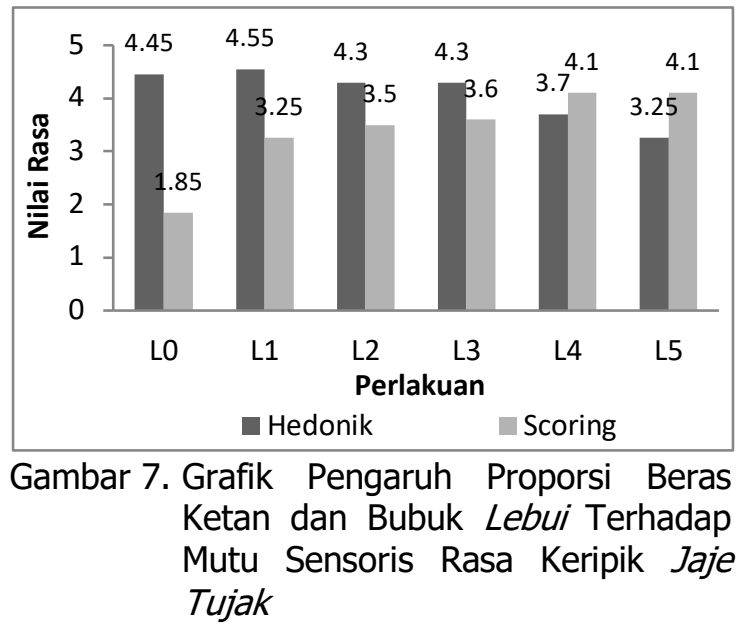

Berdasarkan Gambar 7, menunjukkan bahwa rata-rata panelis memberikan nilai rasa keripik jaje tujak terhadap tingkat kesukaan (hedonik) berkisar antara 3,25-4,55 (agak tidak suka sampai agak suka). Berdasarkan tingkat penilaian (scoring) rata-rata panelis memberikan nilai pada rentang 1,85-4,1 (sangat tidak berasa lebui sampai agak berasa lebul). Menurut Sugito, dkk. (2013), Keripik labu kuning yang paling disukai oleh panelis yaitu semakin tebal irisan keripik menyebabkan semakin gurih keripik yang dihasilkan.

Rasa lebui yang langu akan menyebabkan keripik jaje tujak yang dihasilkan berasa langu atau khas biji-bijian. 
Hasil sensoris rasa secara scoring yaitu semakin banyak penambahan kacang lebui menyebabkan penilaian panelis semakin tinggi yaitu agak berasa lebui sampai berasa pahit. Kacang lebui merupakan leguminosa yang mempunyai rasa yang langu sehingga perlu adanya proses pemanasan untuk menginaktivkan enzim yang menyebabkan rasa langu. Penilaian panelis agak tidak suka terhadap rasa keripik karena berasa pahit terutama pada penambahan kacang lebui sebesar $50 \%$, hal ini dikarenakan kacang lebui dan leguminosa lainnya mempunyai senyawa yang menyebabkan rasa pahit. Hasil penelitian yang dilakukan oleh Jayadi, dkk. (2012), sakko-sakko tipe B (10\% tepung kedelai) memiliki skor tertinggi. Nilai ini lebih tinggi dibanding sakko-sakko tanpa subtitusi. Ini disebabkan karena subtitusi tepung kedelai memiliki ciri khas rasa tersendiri. Di samping itu, juga karena rasa pahit dan rasa kapur yang disebabkan oleh senyawa-senyawa glikosida dalam biji kedelai. Berdasarkan uraian tersebut maka dapat diketahui bahwa perlakuan terbaik untuk rasa dengan kriteria agak tidak berasa lebui yaitu perlakuan L3 (70\%:30\%).

\section{Sensoris Aroma}

Aroma yang diterima oleh hidung dan otak merupakan campuran empat bau utama yaitu harum, asam, tengik dan hangus. Aroma merupakan faktor yang sangat penting untuk menentukan tingkat penerimaan konsumen terhadap suatu produk. (Winarno, 2004). Berdasarkan analisis keragaman (ANOVA), menunjukkan bahwa perlakuan proporsi beras ketan dan bubuk lebui tidak berpengaruh nyata terhadap aroma secara hedonik dan berpengaruh nyata pada scoring keripik jaje tujak.

Berdasarkan Gambar 8, menunjukkan bahwa rata-rata panelis memberikan nilai aroma keripik jaje tujak terhadap tingkat kesukaan (hedonik) berkisar antara 3,8-4,45 (agak tidak suka sampai agak suka). Berdasarkan tingkat penilaian (scoring) ratarata panelis memberikan nilai pada rentang
1,8-3,95 (sangat tidak beraroma lebui sampai agak beraroma lebui).

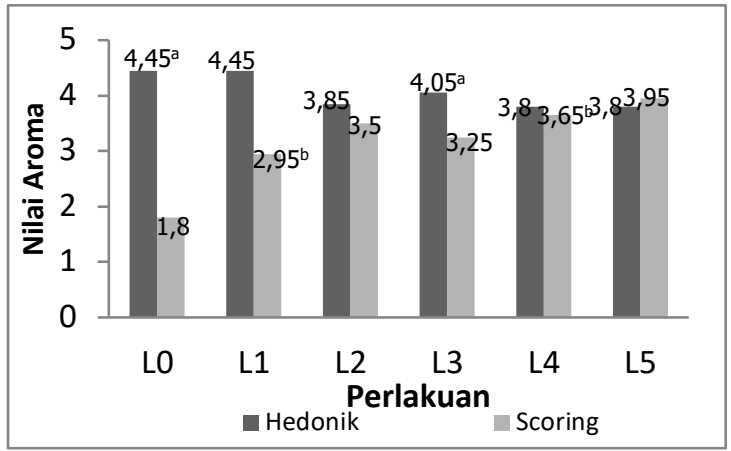

Gambar 8. Grafik Pengaruh Proporsi Beras Ketan dan Bubuk Lebui Terhadap Mutu Sensoris Aroma Keripik Jaje Tujak

Data hasil sensoris aroma secara hedonik yaitu semakin banyak penambahan bubuk lebui maka penilaian panelis terhadap aroma semakin menurun namun tidak signifikan atau tidak berbeda nyata antar perlakuan, hal ini menunjukkan bahwa ratarata panelis menilai keripik jaje tujak dengan proporsi beras ketan dan bubuk lebui mempunyai aroma yang cukup baik atau biasa dengan nilai yang sama dengan perlakuan tanpa penambahan kacang lebui.

Kacang lebui merupakan leguminosa yang mempunyai aroma yang langu sehingga perlu adanya proses pemanasan untuk menginaktivkan enzim yang menyebabkan aroma langu. Menurut Okvitarini (2010), aroma langu pada biji-bijian disebabkan oleh adanya senyawa asam lemak tidak jenuh terutama linoleat yang dikatalisa oleh enzim lipoksigenase. Berdasarkan uraian tersebut maka dapat diketahui bahwa perlakuan terbaik untuk aroma dengan kriteria agak tidak beraroma lebui yaitu perlakuan L3 (70\%:30\%).

\section{Rendemen Bubuk Lebui}

Rendemen adalah persentase perbandingan berat produk yang dihasilkan dengan berat awal bahan (Wijana, dkk., 2012). Cara menghitung rendemen yaitu dengan membagi berat bahan jadi dengan bahan baku dikali $100 \%$. Kacang lebui yang 
Versi Online:

http://www.profood.unram.ac.id/index.php/profood e-ISSN: 2443-3446

digunakan yaitu sebanyak 2,355 $\mathrm{kg}$ dan menghasilkan bubuk lebui sebanyak 2,163 kg. Hasil perhitungan rendemen bubuk lebui yang dihasilkan yaitu $96,778 \%$, sedangkan sisanya sebesar 3,222\% hilang selama proses atau pada tahapan proses yang ada.

\section{KESIMPULAN}

Berdasarkan hasil analisis dan pembahasan dapat disimpulkan bahwa rasio campuran beras ketan dan kacang lebui memberikan pengaruh yang berbeda nyata terhadap total antosianin, aktivitas antioksidan, kadar air, kadar abu, hedonik (tekstur, warna, rasa) dan scoring (tekstur, warna, aroma, rasa). Perlakuan yang memiliki kadar antosianin dan aktivitas antioksidan tertinggi yaitu pada L5 (50\%:50\%) sebesar 47,67 ppm (0,04767 mg/100 g bahan) dan $63 \%$ dengan kadar air dan kadar abu masingmasing $1,77 \%$ dan $5,31 \%$. Proporsi beras ketan dan bubuk lebui pada L3 (70\%:30\%) merupakan hasil terbaik dilihat dari sensoris tekstur, rasa, aroma dan warna yang agak disukai oleh panelis dan secara scoring tekstur agak renyah, berwarna agak putih, agak berasa lebui dan agak tidak beraroma lebui; dengan total antosianin $34,23 \mathrm{ppm}(0,03433$ $\mathrm{mg} / 100 \mathrm{~g}$ bahan), aktivitas antioksidan $50,33 \%$, kadar air 2,01\% dan kadar abu $3,57 \%$.

\section{DAFTAR PUSTAKA}

Ananto, A. D. 2017. Analisis Kandungan Gizi Produk Olahan Sayur Lebui. Pro Food 3 (2):217-221.

Astawan, M. 2004. Makanan Ringan Berkalori Tinggi. IPB. Bogor. http://64.203.71.11/kesehatan/news/se nior/gizi//0407/16/gizi.html. [Diakses tanggal 10 Desember 2018].

Effendi, S. 2012. Teknologi Pengolahan dan Pengawetan Pangan. Alfabeta. Bandung.

Estiasih, T. 2010. Problematika Industri Makanan Ringan (Industri Aneka Makanan Kripik). Pelatihan Makanan
Pro Food (Jurnal Ilmu dan Teknologi Pangan) Vol 5 No. 2 November 2019

ISSN: 2443-1095

Olahan di Kabupaten Mojokerto tanggal 9 Desember 2010.

Firdaus, M., A. A. Prihanto dan R. Nurdiani. 2013. Tanaman Bakaur. Biologi dan Bioaktivitas. UB Press. Malang.

Jauhariah, D. dan F. Ayustaningwarno. 2013. Snack Bar Rendah Fosfor dan Protein Berbasis Produk Olahan Beras. Journal of Nutrition College 2 (2):250-261.

Jayadi, Y., B. Bahar dan S. Sirajuddin. 2012. Pengaruh Subtitusi Tepung Kedelai Terhadap Penerimaan dan Kandungan Gizi Sakko-sakko. Media Gizi Masyarakat Indonesia 1 (2):122-129.

Kartika, B. 1990. Pedoman Uji Indrawi Bahan Pangan. Pusat Antar Pangan dan Gizi UGM. Yogyakarta.

Lingga, L. 2012. Health Secret of Pepper (Cabai). Gramedia. Jakarta.

Marom, A. 2013. Pengaruh Penggunaan Tepung Kulit Ari Biji Kedelai Sebagai Bahan Subtitusi Terhadap Kualitas Choux pastry kering. Skripsi. Fakultas Teknik. Universitas Negeri Semarang. Semarang.

Nurali, E. J. N., M. B. Lelemboto dan Y. Amu. 2010. Pemanfaatan Ubi Jalar (Ipomea batatas L.) Sebagai Bahan Baku Pembuatan Flakes dengan Subtitusi Tepung Kedelai (Glycyne max (L.) MERR). Jurnal Teknologi Pertanian 5 (2):41-51.

Nurrahman, 2015. Evaluasi Komposisi Zat Gizi dan Senyawa Antioksidan Kedelai Hitam dan Kedelai Kuning. Jurnal Aplikasi Teknologi Pangan 4 (3):89-93.

Okvitarini. 2010. Studi Awal Proses Inaktivasi Enzim Lipoksigenase untuk Produksi Tepung Biji Kecipir Sebagai Bahan Baku Tepung Komposit. Prosiding Seminar Nasional UNIMUS. ISBN: 978.979.704.883.9. Semarang.

Oshodi, A. A. dan M. M. Ekperigin. 1989. Functional Properties of Pigeon Pea (Cajanus cajan) Flour. Food Chemistry 34:187-191.

Pusat Kajian Holtikuktura Tropika IPB. 2016. Kacang Gude (Cajanus cajan (L) Mill sp). http://pkht.ipb.ac.id/index.php/2016 102/23/kacang-gude-cajanus-cajan-/mill-sp/. [Diakses tanggal 17 Mei 2018]. 
Versi Online:

http://www.profood.unram.ac.id/index.php/profood e-ISSN: 2443-3446

Putra, D. A. 2018. Pengaruh Rasio Tepung Tempe dan Virgin Coconut Oil (VCO) Terhadap Mutu Nutrisi dan Sensoris Keripik Jagung. Skripsi. Fakultas Teknologi Pangan dan Agroindustri. Universitas Mataram. Mataram.

Ramdani, B. K. 2018. Pengaruh Konsentrasi Tepung Porang Terhadap Sifat Fisikokimia dan Organoleptik Fruit Leather Pisang-Naga Merah. Skripsi. Fakultas Teknologi Pangan dan Agroindustri. Universitas Mataram. Mataram.

Salviana, D. 2018. Analisis Komponen Gizi dan Sensoris Flakes dari Tepung Ubi Jalar Ungu dan Tepung Kacang Gude. Skripsi. Fakultas Teknologi Pangan dan Agroindustri. Universitas Mataram. Mataram.

Sarepoua, E., R. Tangwongchai, B. Suriharn dan K. Lertrat. 2013. Relationship Between Phytochemicals and Antioxidant Activity in Corn Silk. International Food Research Journal 20 (5):2073-2079.

Sudiarto dan Gusmaini. 2004. Pemanfaatan Bahan Organik In Situ untuk Efesiensi Budidaya Jahe yang Berkelanjutan. Jurnal Litbang Pertanian 23 (20:37-45.

Sugito, H. dan Arfah. 2013. Pengaruh Ketebalan Irisan dan Suhu Penggorengan Hampa (Vakum) Terhadap Karakteristik Keripik Labu Kuning (Cucurbita moschata). Jurnal Agroindustri3 (2): 83-97.

Sugiyono. 2002. Teknologi Pengolahan Tepung dan Pati. Departemen Ilmu dan Teknologi Pangan. Fakultas Teknologi Pertanian IPB. Bogor.

Sukenti, K., L. Hakim, S. Indriyani, Y. Purwanto dan P.J. Matthews. 2016. Ethnobotanical study on local cuisine of the Sasak tribe in Lombok Island, Indonesia. Journal of Ethnic Foods 3 (2016):189-200.

Suriani. 2015. Analisis proksimat pada Beras Ketan Varietas Putih (Oryza sativa glutinosa). Al kimia 3 (1):92-101.

Thomas, E. B., E. J. N. Nurali dan T. D. J. Tuju. 2017. Pengaruh Penambahan Tepung Kedelai (Glycine max L.) pada Pembuatan Biskuit Bebas Gluten Bebas
Pro Food (Jurnal IImu dan Teknologi Pangan) Vol 5 No. 2 November 2019

ISSN: 2443-1095

Kasein Berbahan Baku Tepung Pisang Goroho (Musa acuminate L.). Cocos. 1 (7).

Tumbel, N. dan S. Manurung. 2017. Pengaruh Suhu dan Waktu Penggorengan Terhadap Mutu Keripik Nanas Menggunakan Penggoreng Vakum. Jurnal Penelitian Teknologi Industri 9 (1):9-22.

Wardhanu, P. 2009. Pangan Tradisional Berbasis Makanan Tradisional. Wikipedia Indonesia.

Wibowo. 2012. Pengolahan Rumput Laut (Eucheuma cattoni) Menjadi Serbuk Minuman Instant. Jurnal Kelautan dan Perikanan 8(2): 101-109.

Wijana, S., Sucipto dan L.M. Sari. 2012. Pengaruh Suhu dan Waktu Pengeringan Terhadap Aktivitas Antioksidan pada Bubuk Kulit Manggis (Garcinia mangostana L.). Jurnal Teknologi Pertanian 7 (5):1-10.

Winarno, F. G. 2004. Kimia Pangan dan Gizi. Gramedia Pustaka Utama. Jakarta. 